\title{
PENGARUH APLIKASI POC TERHADAP PERTUMBUHAN DAN PRODUKSI RUMPUT GAJAH PADA PEMOTONGAN PERTAMA
}

\author{
Khalidin \\ Program Studi Peternakan Fakultas Pertanian \\ Universitas Jabal Ghafur
}

\begin{abstract}
Abstrak
Penelitian ini dilakukan untuk mengetahui pertumbuhan dan produksi rumput gajah akibat aplikasi POC. Metode yang digunakan adalah Rancangan Acak Kelompok (RAK) yang terdiri dari empat perlakuan dengan enam ulangan. Masing-masing perlakuan adalah P0 (0 ml POC/ltr air sebagai kontrol), P1 (3 ml POC/ltr air), P2 (5 ml POC/ltr air) dan P3 (7 ml POC/ltr air). Parameter yang diamati yaitu tinggi tanaman, jumlah anakan, lingkar batang dan produksi. Hasil penelitian menunjukkan bahwa tinggi, lingkar batang dan produksi rumput gajah sangat nyata dipengaruhi oleh dosis POC yang diaplikasikan yaitu hasil yang tertinggi terdapat pada perlakuan dengan dosis POC $7 \mathrm{ml} /$ liter air. Parameter jumlah anakan rumput gajah berpengaruh nyata akibat dosis POC yang diaplikasikan dimana jumlah anakan terbanyak terdapat pada perlakuan dengan dosis $5 \mathrm{ml} /$ liter air.
\end{abstract}

Kata kunci: POC, rumput gajah, pertumbuhan dan produksi.

\section{PENDAHULUAN}

Latar Belakang

Untuk memenuhi kebutuhan hidup pokok, berproduksi serta berkembang biak ternak rumnansia sangat memerlukan hijauan karena hijauan merupakan pakan utama. Produktifitas ternak yang tinggi perlu didukung dengan ketersediaan hijauan yang cukup dan kontinyu. Salah satu sumber utama hijauan adalah rumput, oleh karena itu rumput harus tersedia dalam jumlah yang cukup, kualitas yang baik dan tersedia secara sepanjang tahun.

Ketersediaan hijauan selalu menjadi masalah bagi para peternak, hal ini disebabkan oleh banyak faktor diantaranya adalah lahan untuk pengembangan hijauan semakin sempit dan kondisi tanahnya yang kurang subur.

Upaya yang dapat dilakukan untuk mengatasi ketersediaan rumput adalah dengan menanam suatu jenis rumput yang mempunyai produksi tinggi dan berkualitas baik. Salah satu rumput yang produksi tinggi dan kualitasnya baik adalah rumput gajah (Pennisetum purpureum). Rumput gajah mempunyai kandungan zat gizi yang cukup tinggi serta disukai oleh ternak ruminansia, dengan rata-rata kandungan zat-zat gizi yaitu: PK 9,66\%, BETN $41,34 \%$, SK $30,86 \%$, lemak 2,24\%, abu 15,96\%, dan total digestible nutrient (TDN) 51\% (Hartadi et al., 1986).

$$
\text { Menurut Reksohadiprodjo }
$$

produksi rumput gajah mencapai 270 ton/ha/ tahun. Rumput gajah dapat tumbuh pada daerah dengan ketinggian $0-3000$ meter di atas permukaan laut (dpl.) dengan curah hujan 1000 $\mathrm{mm}$ tahun/tahun. Hasil penelitian Khalidin et al. (2012), produksi rumput gajah pada pemotongan 50 HST sebanyak 32,83 ton/ha (tanpa perlakuan), 64,33 ton/ha dengan pemupukan pupuk kandang sebanyak 45 ton/ha, sedangkan pada dosis pupuk kandang 45 ton/ha dengan penambahan FMA 10 gr per lubang tanam produksinya dapat mencapai 81,50 ton/ha. Dengan kisaran produksi tersebut kalau pertahunnya dilakukan enam kali pemotongan maka produksi pertahunnya berkisar 196,98 ton; 385,98 ton dan 489 ton. Produksi ini melebihi seperti yang dikemukakan Reksohadiprodjo (1994).

Walaupun selama ini telah dilakukan upaya pengembangan rumput gajah namun pada kenyataannya produksi rumput tersebut banyak yang belum maksimal. Salah satu penyebabnya adalah rendahnya tingkat kesuburan tanah. Kesuburan tanah tentunya terkait erat dengan pemupukan. Dalam melakukan pemupukan rumput gajah sering digunakan pupuk anorganik/pupuk kimia. Penggunaan kimia tentunya memerlukan biaya yang sangat besar. Disamping itu penggunaan dalam jangka waktu lama tanpa ada pemberian pupuk organik tentunya akan menurunkan sifat fisik dan biologi tanah. Kartini (2000) menyatakan penggunaan pupuk kimia dalam periode yang lama merupakan salah satu penyebab degradasi lahan. Pupuk organik yang mudah dan murah produksinya adalah pupuk organik cair (POC). Tarigan (1988) mengemukakan POC 
merupakan pupuk yang dapat memberikan unsur hara yang sesuai dengan kebutuhan tanaman, karena bentuknya yang cair akan mudah mengatur penyerapan komposisi pupuk yang dibutuhkan. Setiawan (1999) menjelaskan bahwa pengaruh dari pemberian pupuk organik cair yaitu memudahkan penyerapan air, memperbaiki kemampuan tanah dalam mengikat air, mengurangi erosi tanah,

Semakin tinggi dosis pupuk yang diberikan baik melalui tanah ataupun daun maka kandungan unsur hara yang diterima oleh tanaman akan semakin tinggi, namun jika pemberian dengan dosisnya berlebihan justru akan mengakibatkan timbulnya gejala kelayuan pada tanaman (Suwandi dan Nurtika, 1987). Untuk mengurangi penggunaan pupuk anorganik/kimia perlu dilakukan berbagai alternatif pemupukan, salah satu yang dapat dilakukan adalah dengan menggunakan pupuk anorganik setengah dari dosis rekomendasi dan dijadikan pilihan pengganti adalah pupuk organik cair (POC). Untuk itu dilakukanlah penelitian guna mengetahui berapa dosis aplikasi POC yang baik terhadap Pertumbuhan dan Hasil Rumput Gajah pada Pemotongan Pertama.

\section{Rumusan Masalah}

Apakah terdapat pengaruh dari dosis POC terhadap Pertumbuhan dan Hasil Rumput Gajah pada Pemotongan Pertama.

\section{Tujuan Penelitian}

Untuk mengetahui dosis POC terbaik untuk Pertumbuhan dan Hasil Rumput Gajah pada Pemotongan Pertama.

\section{Hipotesis}

Dosis POC berpengaruh terhadap Pertumbuhan dan Hasil Rumput Gajah pada Pemotongan Pertama.

\section{METODE PENELITIAN}

\section{Waktu dan Tempat Penelitian}

Penelitian akan dilaksanakan di kebun penelitian Prodi Peternakan Fakultas Pertanian Universitas Jabal Ghafur yang dimulai pada tanggal 10 Pebruari sampai dengan 1 April 2017.

\section{Materi dan Alat Penelitian}

Materi yang digunakan dalam penelitian ini terdiri dari Stek rumput gajah yang diambil dari kebun Prodi Peternakan Fakultas Pertanian
Universitas Jabal Ghafur. Pupuk Urea, $\mathrm{KCl}$ dan SP 36. Pupuk Organik Cair hasil fermentasi berbahan dasar kotoran sapi.

Alat-alat Alat-alat yang digunakan antara lain: cangkul, skop, garu, parang, sabit, timbangan, meteran serta garpu pohon untuk mengukur diameter batang.

\section{Prosedur Penelitian}

- Lahan penelitian diolah dengan cara dicangkul dan kemudian dibuat plot dengan ukuran 2 x 2 meter.

- Pupuk anorganik diberikan dengan cara ditabur merata kemudian digaru agar bercampur merata dengan tanah

- Penanaman rumput gajah dilakukan dengan menggunakan stek yang masing-masing panjangnya 3 ruas dengan cara membenamkan sedalam 1 ruas sebanyak 1 stek di setiap lubangnya dengan jarak tanam $50 \mathrm{~cm} \times 50 \mathrm{~cm}$.

- Penyiraman dilakukan setelah tanam sampai mencapai kapasitas lapang, selanjutnya penyiraman dilakukan sesuai kondisi kelembaban tanah. Rumput yang tidak tumbuh segera disulam dalam masa satu minggu setelah tanam.

- Penyiangan dilakukan secara manual dengan cara mencabut setiap gulma yang terdapat pada setiap plot.

- Pemberian POC dilakukan dengan cara menyiram dengan memakai gembor kapasitas 15 liter air.

\section{Rancangan Penelitian}

Penelitian dilakukan dengan menggunakan Rancangan Acak Kelompok (RAK) yang terdiri dari 4 perlakuan dengan 6 ulangan.Data yang diperoleh dianalisis sidik ragam dengan model matematik sbb:

Yijk $=m+b i+t j+e i j k$

Keterangan:

$$
\begin{aligned}
\mathrm{Y}_{\mathrm{ijk}}= & \text { Nilai pengamatan pada ulangan ke- } \\
& \mathrm{i} \text { dan perlakuan ke- } \mathrm{j} \\
\mu \quad= & \text { Rata-rata umum } \\
\beta \mathrm{i}= & \text { pengaruh ulangan ke- } \mathrm{i} \\
\tau \mathrm{j}= & \text { Pengaruh perlakuan ke- } \mathrm{j} \\
\varepsilon \mathrm{ij}= & \text { Kesalahan (galat) percobaan pada } \\
& \text { ulangan ke-i dan perlakuan ke- } \mathrm{j}
\end{aligned}
$$


Jika terdapat pengaruh nyata atau sangat nyata maka dilanjutkan dengan uji BNT.

Adapun perlakuan dari penelitian ini adalah:

$1 \mathrm{P}_{0}=$ Tanpa POC

$2 \mathrm{P}_{1}=3 \mathrm{ml} \mathrm{POC} / \mathrm{ltr}$ air

$3 \mathrm{P}_{2}=5 \mathrm{ml} \mathrm{POC} / \mathrm{ltr}$ air

$4 \mathrm{P}_{3}=7 \mathrm{ml} \mathrm{POC} / \mathrm{ltr}$ air

\section{Pengamatan}

Variable yang diamati yaitu: tinggi tanaman, jumlah anakan, lingkar batang dan produksi

\section{HASIL DAN PEMBAHASAN \\ Tinggi Tanaman}

Data tinggi tanaman hasil penelitian yang dianalisis dengan menggunakan sidik ragam menunjukkan bahwa tinggi rumput gajah sangat nyata dipengaruhi oleh dosis POC yang diaplikasikan. Rata-rata tingginya dapat dilihat pada Gambar 1 dibawah.

\section{Gambar 1.}

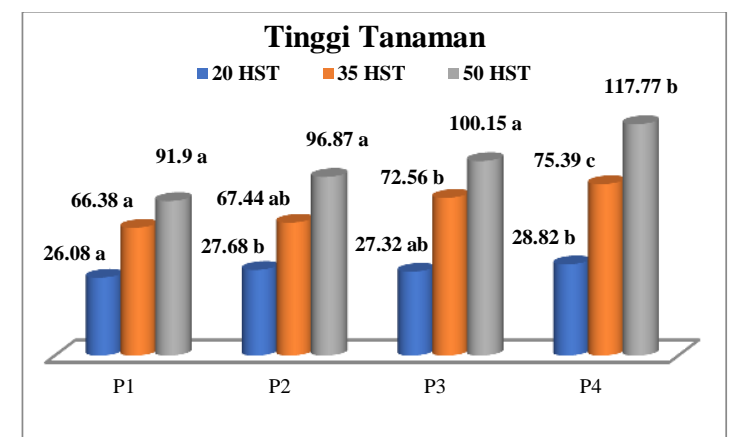

Keterangan: Angka yang diikuti oleh huruf yang sama tidak berbeda nyata, huruf berbeda menunjukkan perbedaan yang sangat nyata (Uji BNJ)

Pada umur 20 HST rumput gajah tertinggi terdapat pada perlakuan dosis POC $7 \mathrm{ml} / \mathrm{lt}$ $(28,82 \mathrm{~cm})$ berbeda sangat nyata dengan perlakuan tanpa POC $(26,08 \mathrm{~cm})$ namun tidak berbeda sangat nyata dengan dosis $3 \mathrm{ml} / \mathrm{lt}(27,68$ $\mathrm{cm})$ dan $5 \mathrm{ml} / \mathrm{lt}(27,32 \mathrm{~cm})$.

Pada umur 20 HST juga terlihat bahwa dosis POC $5 \mathrm{ml} / \mathrm{tt}(27,32 \mathrm{~cm})$ tinggi rumput gajah lebih rendah dengan perlakuan dosis 3 $\mathrm{ml} / \mathrm{lt}(67,44 \mathrm{~cm})$, hal ini mungkin disebabkan tingkat pertumbuhan rumput pada umur-umur awal belum begitu sempurna dimana perakarannya belum begitu menyebar sehingga unsur hara yang tersedia belum dapat dimanfaatkan secara maksimal oleh tanaman.
Pada umur 35 dan 50 HST terlihat bahwa semakin tinggi aplikasi dosis POC semakin tinggi rumput gajahnya. Hasil penelitian Khalidin et al. (2012), bahwa rumput gajah yang tertinggi pertumbuhan dimasa awalnya terdapat pada perlakuan pupuk kandang 15 ton/ha bukan pada dosis pupuk kandang 30 dan 45 ton/ha. Sedangkan pada umur 50 HST pertumbuhan tertinggi baru terdapat pada perlakuan 45 ton/ha pupuk kandang (dosis tertinggi)..

Pupuk organik cair umumnya mengandung unsur hara makro dan mikro cukup lengkap (Rizqiani et al., 2007). POC mengandung unsur hara makro $\mathrm{N}, \mathrm{P}$, dan $\mathrm{K}$. unsur $\mathrm{N}$ berfungsi merangsang pertumbuhan vegetatif tanaman diantaranya tinggi tanaman. Pada perlakuan dengan takaran POC terbanyak maka kandungan unsur hara tanahnya juga semakin banyak, hal ini akan memberikan asupan unsur hara untuk menunjang pertumbuhan yang maksimal.

\section{Jumlah Anakan}

Data jumlah anakan hasil penelitian yang dianalisis dengan sidik ragam menunjukkan bahwa hanya pada umur 50 HST jumlah anakan rumput gajah berpengaruh nyata akibat dosis POC yang diaplikasikan. Rata-rata tingginya dapat dilihat pada Gambar 2 dibawah.

\section{Gambar 2.}

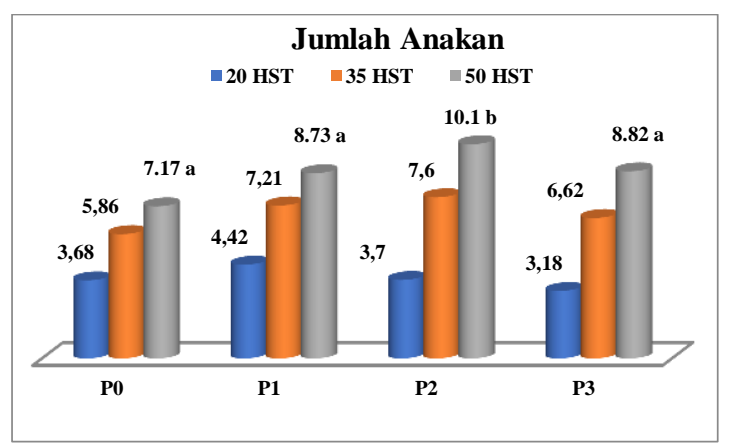

Keterangan: Angka yang diikuti oleh huruf yang sama tidak berbeda nyata, huruf yang berbeda menunjukkan perbedaan yang nyata (Uji BNJ)

Gambar 2 di atas memperlihatkan jumlah anakan dari hasil penelitian dalam hal perlakuan dengan dosis tertinggi tidak menghasilkan jumlah anakan tertinggi. Lain halnya dengan tinggi tanaman, dimana pada perlakuan dosis tertinggi akan menghasilkan tinggi tanaman yang lebih tinggi.

Hal ini memperlihatkan bahwa ketersediaan unsur hara akan dimanfaatkan oleh tanaman rumput gajah lebih dominan untuk pertumbuhan tingginya dan memperbesar 
lingkar batang bukan untuk memperbanyak jumlah anakan.

\section{Lingkar Batang}

Data lingkar batang hasil penelitian yang dianalisis dengan menggunakan sidik ragam menunjukkan bahwa lingkar batang rumput gajah sangat nyata dipengaruhi oleh dosis POC yang diaplikasikan mulai dari umur 20 sampai dengan 50 HST. Rata-rata tingginya dapat dilihat pada Gambar 3 dibawah.

Gambar 3.

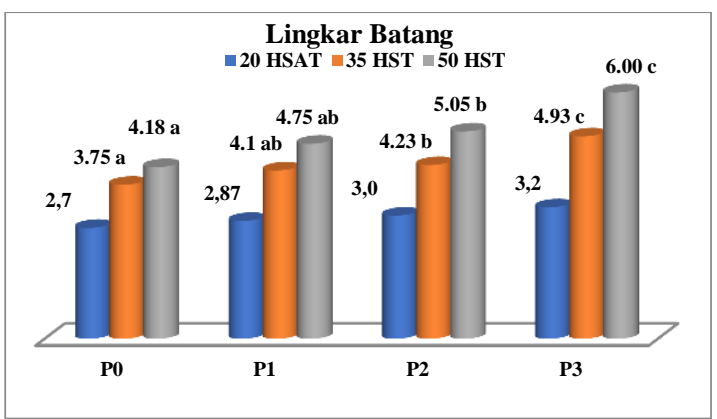

Keterangan: Angka yang diikuti oleh huruf yang sama tidak berbeda nyata, huruf berbeda menunjukkan perbedaan yang sangat nyata (Uji BNJ)

Gambar 3 di atas memperlihatkan bahwa semakin tinggi dosis POC yang diaplikasikan semakin besar lingkar batang rumput gajah. Pada umur 50 HST lingkar batang terbesar terdapat pada perlakuan P3 $(6 \mathrm{~cm})$ berbeda sangat nyata dengan perlakuan lainnya. Semakin tinggi disis POC yang diaplikasikan maka semakin banyak unsur hara yang tersedia bagi tanaman, terutama adalah unsur hara makro yaitu $\mathrm{N}, \mathrm{P}$ dan $\mathrm{K}$. unsur hara yang tersedia ini lebih dominan dimanfaatkan untuk untuk lingkar batang. Puspadewi (2016) mengemukakan bahwa pengaruh pupuk $\mathrm{N}, \mathrm{P}, \mathrm{K}$ sangat besar dalam mendukung pertumbuhan tinggi dan diameter batang pada tanaman jagung. Perlakuan yang tidak mengandung pupuk N, P, $\mathrm{K}$ akan menunjukkan pertumbuhan yang lebih lambat dibandingkan dengan perlakuan lain yang mengandung pupuk N, P, K. Ketersediaan unsur hara terutama yang ensial akan digunakan untuk pertumbuhan dan perkembangan tanaman. Penyerapan unsur hara oleh tanaman tidak diserap sekaligus untuk pertumbuhan tinggi dan diameter batang. Pada awal pertanaman unsur hara akan tertuju pada pertumbuhan tinggi tanaman dan saat mendekati masa akhir vegetatif unsur hara akan diserap untuk pertumbuhan diameter batang.

\section{Produksi}

Hasil analisis ragam dari data produksi rumput gajah hasil penelitian menunjukkan bahwa produksi sangat nyata dipengaruhi oleh dosis POC. Rata-rata produksi rumput gajah dapat dilihat pada Gambar 4 dibawah.

\section{Gambar 4}

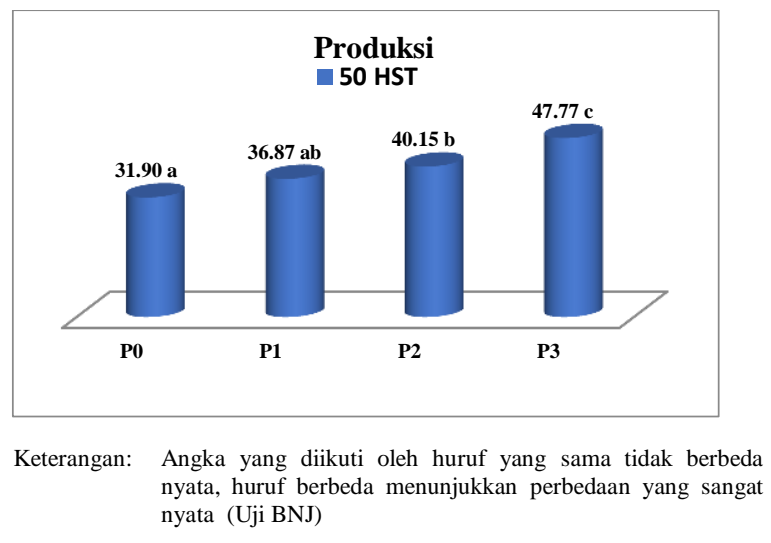

Gambar 4 di atas menunjukkan bahwa produksi rumput gajah tertinggi terdapat pada perlakuan P3 (47,77 ton/ha), sedangkan produksi terendah terdapat pada perlakuan P0 (31,90 ton/ha). Produksi rumput gajah dari dua perlakuan ini menunjukkan perbedaan yang sangat nyata, begitu juga dengan P1 dan P2 masing-masing hasilnya yaitu 36,87 dan 40,15 ton/ha. Adapun selisih produksi dapat dilihat pada gambar 5 berikut.

\section{Gambar 5}

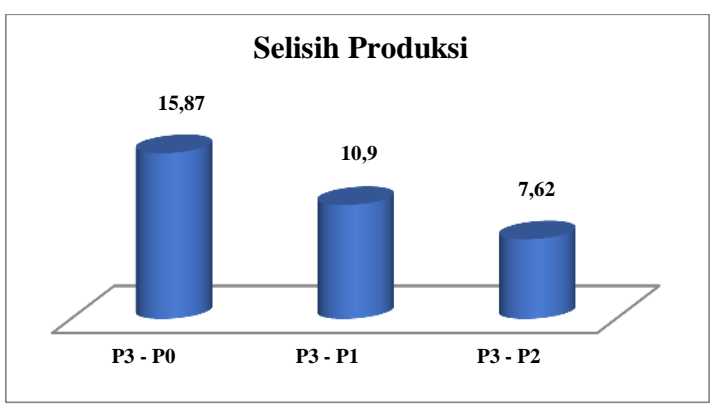

Pada gambar di atas terlihat jelas selisih produksi yang sangat tinggi akibat aplikasi POC. Antara perlakuan P3 dengan P0 terdapat selisih produksi sebesar 15,87 ton, P3 dengan P1 sebesar 10,9 ton dan P3 dengan P2 terdapat selisih produksi sebesar 7,62 ton. Hasil penelitian Muhakka et al. (2012) juga menunjukkan bahwa pemberian pupuk cair berpengaruh sangat nyata terhadap produksi segar dan produksi kering rumput gajah Taiwan. Hal ini disebabkan karena pupuk organik cair mengandung berbagai unsur hara yang 
dibutuhkan tanaman sehingga pemberian pupuk organik cair dapat berpengaruh terhadap pertumbuhan tanaman. Hal ini sesuai dengan penjelasan Lakitan (1996) bahwa pupuk cair juga berpengaruh langsung terhadap fisiologi tanaman seperti meningkatkan pertumbuhan tanaman, serta meningkatkan produksi tanaman. Unsur $\mathrm{N}$ sangat berpengaruh karena merupakan unsur penting bagi pembelahan sel yang akan menunjang pertumbuhan tanaman baik bertambahnya ukuran dan volume (Puspadewi et al., 2016).

\section{KESIMPULAN DAN SARAN Kesimpulan}

- Tinggi rumput gajah sangat nyata dipengaruhi oleh dosis POC yang diaplikasikan dimana tinggi rumput gajah yang tertinggi terdapat pada perlakuan dengan dosis $7 \mathrm{ml} /$ liter air.

- Jumlah anakan rumput gajah berpengaruh nyata akibat dosis POC yang diaplikasikan dimana jumlah anakan terbanyak terdapat pada perlakuan dengan dosis $5 \mathrm{ml} /$ liter air.

- Lingkar batang rumput gajah sangat nyata dipengaruhi oleh dosis POC yang diaplikasikan dimana lingkat batang terbesar terdapat pada perlakuan dengan dosis $7 \mathrm{ml} /$ liter air.

- Produksi rumput sangat nyata dipengaruhi oleh dosis POC dimana produksi tertinggi juga terdapat pada perlakuan dengan dosis $7 \mathrm{ml} /$ liter air.

\section{Saran}

- Perlu dilakukan penelitian yang sama untuk melihat pengaruhnya pada pemotongan ke dua.

- Perlu dilakukan penelitian lebih lanjut untuk mengetahui berapa dosis POC maksimal yang dapat diaplikasikan pada rumput gajah.

\section{DAFTAR PUSTAKA}

Hartadi, H., S. Reksohadiprodjo dan A.D. Tillman. 1986. Tabel Komposisi Pakan untuk Indonesia. Gadjah Mada University Press. Yogyakarta.

Kartini. 2000. Pertanian Organik sebagai Pertanian Masa Depan. Prosiding Seminar Nasional Pengembangan Teknologi Pertanian dalam Upaya Mendukung Ketahanan Pangan Nasional. Pusat
Penelitian dan Pengembangan Sosial Ekonomi Pertanian. Universitas Udayana. Denpasar.

Khalidin, Tuti A. dan Fikrinda (2012). Pengaruh FMA dan Pupuk Kandang terhadap Produksi dan Kualitas Rumput Gajah (Pennisetum purpereum Schum). Jurnal Manajemen Sumberdaya Lahan. 1(2):180184. Prodi. Magister Sumberdaya Lahan (KSDL) Unsyiah dan Himpunan Ilmu Tanah Indonesia (HITI). Komda Aceh.

Lakitan, B. 1996. Fisiologi Pertumbuhandan Perkembangan Tanaman. Cetakan I. PT. Raja Grafindo Persada. Jakarta.

Muhakka., A. Napoleon dan P. Rosa. 2012. Pengaruh Pemberian Pupuk Cair Terhadap Produksi Rumput Gajah Taiwan (Pennisetum Purpureum Schumach). Jurnal Peternakan Sriwijaya (JPS). 1(1): 48-54.

Pipit P., Darwin P., Muhammad S.H., dan. Yohannes C.G. (2013). Pengaruh Frekuensi Penyemprotan dan Konsentrasi Pupuk Organik Cair pada Pertumbuhan dan Produksi Tanaman Tomat (Lycopersicum esculentum Mill.) Jurnal Agrotek Tropika. 1(3): 264-268.

Reksohadiprodjo (1994). Produksi Hijauan Makanan Ternak Tropik. BPFE Universitas Gajah Mada . Yogyakarta.

Rizqiani, N.F., E. Ambarwati, dan N.W. Yuwono (2007). Pengaruh Dosis dan Frekuensi Pemberian Pupuk Organik Cair terhadap Pertumbuhan dan Hasil Buncis (Phaseolus vulgaris L.) Dataran Rendah. Jurnal Ilmu Tanah dan Lingkungan. 7(1):43-53.

Sajimin, I. P. Kompiang, Supriyati dan N. P. Suratmini. 2001. Penggunaan Biofertilizer untuk Penigkatan Produktifitas Hijauan Pakan Rumput Gajah (Pennisetum purpureum cv Afrika) pada Lahan Marjinal di Subang Jawa Barat. Media Peternakan. 24 (2) : 46 - 50.

Suwandi dan N, Nurtika. 1997. Pengaruh Pupuk Cair Biokimia "Sari Humus" pada Tanaman Kubis. Buletin Penelitian Hortikultura 15(20): 213-218.

Puspadewi, S., W. Sutari dan Kusumiyati 2016. Pengaruh Konsentrasi Pupuk Organik Cair (POC) dan Dosis Pupuk N, P, K terhadap Pertumbuhan dan Hasil Tanaman Jagung Manis (Zeamays L. var Rugosa Bonaf) kultivar Talenta. Jurnal Kultivasi. 15(3): 208-216. 